\title{
Assessment of Farm management risk factors of contracting haemoparasitic infections in Pastoralist and Sedentary cattle in Soba Local Government Area, Kaduna State, Nigeria
}

${ }^{1 *}$ Danbirni, S., ${ }^{2}$ Daudu, B. B., ${ }^{1}$ Saidu, S. N. A. and ${ }^{1}$ Tekdek, L. B.

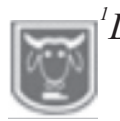
${ }^{\prime}$ Department of Veterinary Medicine, Ahmadu Bello University, Zaria, Nigeria ${ }^{2}$ Epidemiology Unit, Vet. Services Division, Min. of Agric. Jalingo, Taraba State, Nigeria

Abstract *Corresponding Author: drdanbirni07@yahoo.com

The major cattle management system observed in Soba Local Government Area was pastoral husbandry system. Under this system, cattle were extensively grazed on established forages of Kaduna State forests and were exposed to various arthropod vectors of haemoparasites. These haemoparasites are a serious threat to food security in Soba LGA due to their influence on cattle productivity. Questionnaires were used in assessing some farm management risk factors of contracting haemoparasitic infections in both pastoralist and sedentary herds in Soba LGA. A total of 24 herdsmen made up of 20 pastoralists and 4 sedentary herdsmen were interviewed. The study revealed, that some herd management practices were observed to have constituted risks to acquiring haemoparasitic infections in both pastoralist and sedentary herds in the study area. For instance, vectors of haemoparasites such as ticks and biting flies aside Glossina were present in both pastoralist and sedentary herds in the study area. Some farm management practices such as screening of herds for haemoparasites, treatment of it once in 12 months and quarantining of new stock before adding to the existing herds were found not to be carried. Thus, constituted risk factors in the herds. This preliminary study, provided evidence of the possible arthropod vectors (ticks and biting flies) that may be involved in the transmission of haemoparasites to cattle in Soba LGA of Kaduna State. It is envisaged that this survey will stimulate more studies to determine the prevalence of haemoparasites in cattle in Soba LGA of Kaduna State.

Keywords: Risk factors, Haemoparasitism, Pastoralist, Sedentary, Herds, Soba LGA.

\section{Introduction}

Cattle production provides an essential source of animal protein through meat and milk. Beef (meat from cattle), is the third most widely consumed meat in the world, accounting for about $25 \%$ of meat production worldwide, after pork and poultry at $38 \%$ and $30 \%$, respectively (Dreyer et al., 1998; Dold and Cocks, 2001). The Cattle industry also generates employment, income, farm power and organic manure for arable Agriculture in the Sudan-Sahelian ecological zones of Nigeria (Ikhatua and Asaka, 2000). Among the nomadic Fulani and Shuwa-Arab pastoralists, the ownership of cattle also serves as an index of social prestige (Lamorde, 1998). Furthermore, their products such as hides, bones and blood serve as raw materials for industries (Ikhatua and Asaka, 2000).

Pastoralist herd is nomadic in nature and involves migrating from one location to another in search of feed or grazing and watering areas. Cattle are kept in the open without housing facilities. The animals have little or no healthcare services and no breeding programme (Obadiah and Shekaro, 2012; Lorusso et al., 2013). Generally, they are kept under an extensive cattle management system. About $90 \%$ of the cattle population in Nigeria are raised under the pastoral husbandry system by Fulani herders (Lorusso et al., 2013). Under this system, cattle are grazed on established forage land and forests and may 
be exposed to various arthropod vectors of haemoparasites (Obadiah and Shekaro, 2012). Among parasitic diseases of cattle, haemoparasitism constitutes a disease entity of great economic importance (Jongejan and Uilenberg, 2004; Salih et al., 2015) and has been recognized as a serious threat to food security in Nigeria. However, the impact of haemoparasites on cattle productivity is difficult to quantify (Singla et al., 2007; Samdi et al., 2010) but losses in traction power, milk and beef production as well as costs of control programmes have been ascribed to haemoparasites (ILR, 1997).

The general clinical signs that these haemoparasites cause in cattle include; pale mucus membrane and/or jaundice, due to destruction of red blood cells, anorexia, weight loss, abortion, prolonged calving interval and infertility (Akande et al., 2010). Some haemoparasites are only evident when the host is undergoing clinical response to infection, while other species of the same genera may be easily seen in blood smears from apparently heathy animals (Luckins, 1992).

Haemoparasites and heir vectors have a global distribution and are important parasites in subSaharan Africa (Okorafor and Nzeako, 2014). Their prevalence in cattle in Nigeria is generally considered to be very high due to the preponderance of their arthropod vectors (Biu and Kabono, 2005; Kamani et al., 2010; Musa et al., 2014; Okorafor and Nzeakor, 2014).

There seem to be no available data on haemoparasites in cattle management systems in Soba Local Government Area (LGA) of Kaduna State, Nigeria. Requests for screening and treatment of cattle for haemoparasitic diseases by herds owners is rare in the study area. Most cattle may be infected with haemoparasites without apparent clinical signs and this may serve as a source of infection to other susceptible cattle in the area. There is the need to generate data in order to assess the occurrence of some possible farm management risk factors of contracting haemoparasitic infections in pastoralist and sedentary cattle in Soba L.G.A. This may assist governments and other stakeholders in planning for the control of vectors of haemoparasites as well as enlightening cattle farmers on some farm management system risk factors that may enhance haemoparasitisms in their herds.

\section{Materials and methods Location}

The study was carried out in Soba LGA. Soba LGA, which is one of the 23 LGAs in Kaduna State. It is located in the northern part of Kaduna State between latitude $10^{\circ}$ $58^{\prime} 52^{\prime} .79^{\prime \prime} \mathrm{N}$ and longitude $8^{\circ} 03^{\prime} 26^{\prime} .96^{\prime \prime}$. It has an estimated human population of 238,719 comprising predominantly traders, cattle rearers and farmers (Abubakar et al., 2016). The climate is that of the Northern Guinea Savannah favourable for rearing of cattle and other livestock.

\section{Study design/ questionnaire administration:}

A cross sectional study was carried out using a closed ended designed questionnaire. The questions included, the identification of the types of arthropod vectors observed in the herds, how they are gotten rid of, how often the ectoparasites are been controlled in the herds, for how long the herdsmen have been taking their cattle to a known tsetse infested areas in search of greener pasture during feed scarcity, the last time the herdsmen have ever screened their herds of haemoparasites, the last time the herds were treated against haemoparasites, the last time the herdsmen introduced a new animal into the herd, what did the herdsmen do before adding a new stock into your herd etc.

Herdsmen practicing Pastoralist (Plate 1) or 
Sedentary herd (Plate 2) management systems and were willing to be interviewed were selected using purposeful/judgement sampling method. The questionnaires were administered to the herdsmen in form of interviews. The questions were interpreted to the herdsmen using Hausa language as it was the commonest language of communication among the herdsmen and their responses were recorded. A structured questionnaire was administered to twentyfour respondents (Twenty pastoralists and four sedentary herdsmen). The interviews were conducted immediately after their daily morning routine of cow milking. The timing was deliberate in order to get their maximum attention.

\section{Data analyses}

Data obtained were expressed as descriptive statistics and Chi square was used to compare the occurrences of haemoparasites in pastoralist and sedentary cattle farm management systems using Statistical Package for Social Sciences (SPSS) version 20.

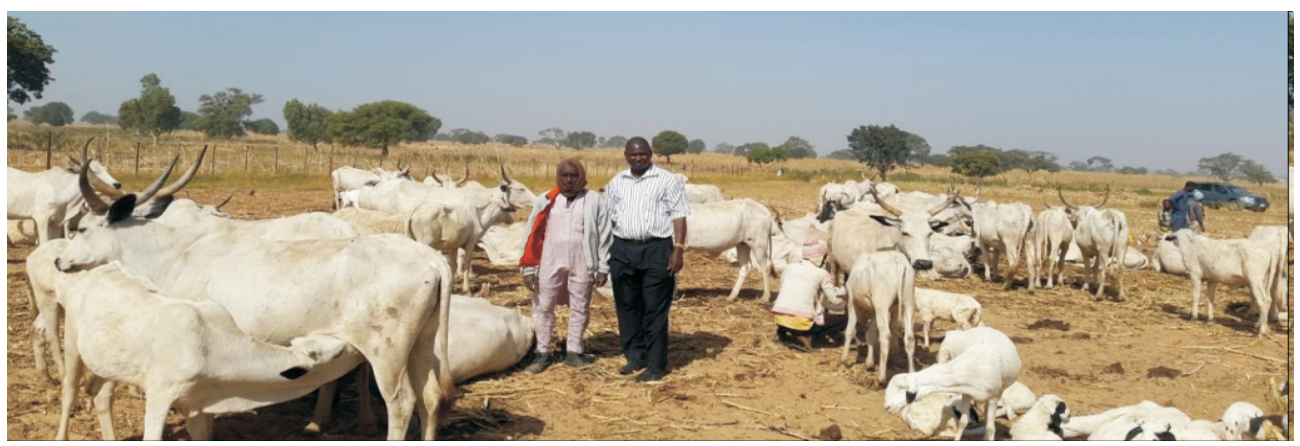

Plate 1: Pastoralist cattle herd in Soba Local Government Area, Kaduna State

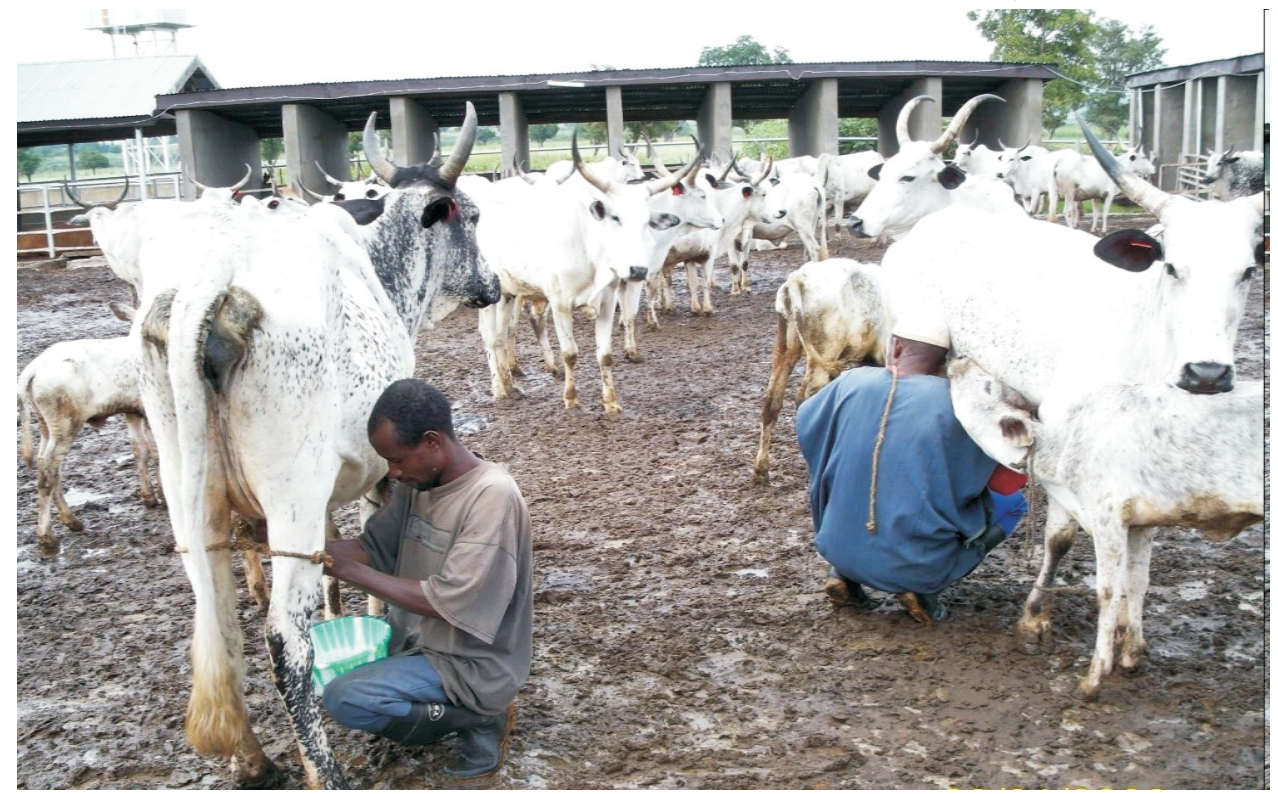

Plate 2: Sedentary cattle herd in Soba Local Government Area, Kaduna State 


\section{Results}

Of the 24 herdsmen (20 pastoralists and 4 sedentary) that were interviewed, all $(100 \%)$ indicated that ticks and other biting flies were the arthropod vectors that may be transmitting haemoparasitic infections in the study area (Table 1). Hand picking of ticks on the cattle and smoke repelling of biting flies were the commonest practice for controlling ticks $(70.8 \%)$. This was especially observed in the pastoralist herds $(85.0 \%)$. Some herdsmen practiced dipping and or pour-on $(16.7 \%)$ especially the sedentary herds $(100.0 \%)$ while other herdsmen practiced hand picking of ticks only $(12.5 \%)$ which was observed in $15.0 \%$ of the pastoralists. There was a significant difference $(p<0.05)$ in the control of ticks and biting flies between pastoralist and sedentary herds. The risk of contracting haemoparasitic infections in both pastoralist and sedentary herds (Table 1) was statistically significant $(\mathrm{p}<0.05)$. About $83.3 \%$ of the herdsmen control vectors anytime they were seen on the cattle, especially in the pastoralist herds $(100.0 \%)$ while others control vectors during wet season only (16.7\%), especially those in the sedentary herds $(100.0 \%)$. There was a significant difference $(\mathrm{p}<0.05)$ in the risk of contracting haemoparasitic infections in both pastoralist and sedentary herds considering the frequency of controlling vectors in the herds (Table 1). About $66.7 \%$ of the herdsmen had taken their herds to a known Glossina infested area about 1-2 years previously, especially the pastoralist herds $(80.0 \%)$, about $20.8 \%$ of the herdsmen had never taken their herds for grazing in Glossina infested area especially the sedentary herds (100.0\%) while $12.5 \%$ of herdsmen had done so over the previous 2 years especially $15.0 \%$ of the pastoralist herdsmen (Table 1). Of all the herdsmen, $75.0 \%$ had never screened their herds for haemoparasites especially the pastoralist herdsmen

(90.0\%), while $20.8 \%$ of the herdsmen did so over 12 months especially in the sedentary system $(100 \%)$. The other $4.2 \%$ of the herdsmen did so within 0-12 months, especially $50.0 \%$ were from pastoralists. There was a significant difference $(p<0.05)$ in the risk of acquiring haemoparasitic infections between herdsmen who screened their herds of haemoparasites and those who did not (Table 1). Of all the herdsmen, $75.0 \%$ had treated their herds of haemoparasitic infection in 12 months in which $100.0 \%$ were from the sedentary and $50.0 \%$ were from the pastoralists herdsmen. Of all the herdsmen, $12.5 \%$ had never treated their cattle against haemoparasitism of which $10.0 \%$ were of the pastoralists, while some $(8.3 \%)$ of the herdsmen did theirs within the last 7-12 months especially $10.0 \%$ of the pastoralist. Other herdsmen $(10.0 \%)$ treated their cattle within the last 16 months. There was a significant difference $(p<0.05)$ in the risk of contracting haemoparasitic infections between herdsmen who treated their herds of haemoparasitic infections and those who did not (Table 1). Most (37.5\%) of all the herdsmen had introduced a new stock into their herds in the last 12 months especially $50.0 \%$ were of the sedentary and $35.0 \%$ were of the pastoralists herdsmen while $25.0 \%$ of all the herdsmen did so about 7-12 months previously especially $25.0 \%$ were of both the pastoralist and the sedentary herdsmen and $20.8 \%$ herdsmen had never done so especially among $25.0 \%$ of the pastoralists. The rest $(16.7 \%)$ of the herdsmen treated their cattle within the last 1-6 months especially the remaining $15.0 \%$ of the pastoralists. There was no significant difference $(p>0.05)$ in the risk of acquiring haemoparasitic infections between those who introduced new stock into their existing herds and those who did not (Table 1). Of all herdsmen, $79.2 \%$ did nothing to 


\section{Danbirni, Daudu, Saidu and Tekdek}

reduce or prevent the risk of acquiring haemoparatic infections when stocks were to be added into the existing herds in especially $95.0 \%$ of both the pastoralists and the sedentary herdsmen; while $8.3 \%$ of the herdsmen do quarantined the new stock for 2 weeks combined with deworming and/or administration of oxytetracycline long acting injection in especially $50.0 \%$ of the sedentary herdsmen while $4.2 \%$ of herdsmen do practiced 2 weeks of quarantine only, especially $5.0 \%$ of the pastoralists and there was a significant difference $(p<0.05)$ in the risk of acquiring haemoparasitic infections in the herds of those herdsmen who practice 2 weeks of quarantining with or without deworming and/or with oxytetracycline long acting injection and those who do not (Table 1).

Table 1: Responses of herdsmen to the assessment of risk factors of contracting haemoparasitic infections in pastoralist and sedentary cattle in Soba local government areas, Kaduna State

\begin{tabular}{|c|c|c|c|c|}
\hline Risk Factors of acquiring haemoparasite & $\begin{array}{l}\text { Pastoralist } \\
\text { herd } \\
\mathbf{n = 2 0}(\%)\end{array}$ & $\begin{array}{l}\text { Sedentary } \\
\text { herd } \\
n=4(\%)\end{array}$ & $\begin{array}{l}\text { Total } \\
\text { responses } \\
\text { from the } \\
\text { herdsmen }\end{array}$ & $\begin{array}{l}\text { p-value } \\
(<0.05)\end{array}$ \\
\hline \multicolumn{5}{|l|}{ 1. Arthropod vector type in the herd: } \\
\hline 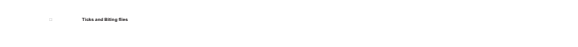 & $20(100.0)$ & $4(100.0)$ & 24(100.0) & \\
\hline \multicolumn{5}{|l|}{ 2. Method of vector control } \\
\hline$\square$ Hand picking & $3(15.0)$ & $0(0.0)$ & $3(12.5)$ & \\
\hline$\square$ Hand picking and smoke application & $17(85.0)$ & $0(0.0)$ & 17(70.8) & 0.000 \\
\hline$\square$ Dipping and pour-on application & $0(0.0)$ & $4(100.0)$ & $4(16.7)$ & \\
\hline & $20(100.0)$ & $4(100.0)$ & 24(100.0) & \\
\hline \multicolumn{5}{|l|}{ Total } \\
\hline \multicolumn{5}{|l|}{ 3. Frequency of vector control } \\
\hline \multirow[t]{2}{*}{$\square$ Any time vectors are seen in the herd } & $20(100.0)$ & $0(0.0)$ & $20(83.3)$ & 0.000 \\
\hline & $20(100.0)$ & $4(100.0)$ & $24(100.0)$ & \\
\hline \multicolumn{5}{|l|}{$\begin{array}{l}\text { Total } \\
\text { 4. Duration of visiting to graze } \\
\text { in tsetse flies areas }\end{array}$} \\
\hline$\square \quad 0$ year & $1(5.0)$ & $4(100.0)$ & $5(20.8)$ & \\
\hline$\square \quad 1-2$ years & $16(80.0)$ & $0(0.0)$ & $16(66.7)$ & \\
\hline$\square>2$ years & $3(15.0)$ & $0(0.0)$ & $3(12.5)$ & \\
\hline Total & $20(100.0)$ & $4(100.0)$ & $24(100.0)$ & \\
\hline \multicolumn{5}{|l|}{$\begin{array}{l}\text { 5. Last time herds were } \\
\text { screened for } \\
\text { Haemoparasites }\end{array}$} \\
\hline$\square \quad 0-12$ months & $1(50.0)$ & $0(0.0)$ & $1(4.2)$ & \\
\hline$\square>12$ months & $1(50.0)$ & $4(100.0)$ & $5(20.8)$ & 0.000 \\
\hline$\square \quad$ Never & $18(90.0)$ & $0(0.0)$ & $18(75.0)$ & \\
\hline Total & $20(100.0)$ & $4(100.0)$ & $24(100.0)$ & \\
\hline \multicolumn{5}{|l|}{$\begin{array}{l}\text { 6. Last time herds were treated } \\
\text { against Haemoparasites }\end{array}$} \\
\hline$\square \quad 1-6$ months & $2(10.0)$ & $0(0.0)$ & $1(4.2)$ & 0.000 \\
\hline$\square \quad 7-12$ months & $2(10.0)$ & $0(0.0)$ & $2(8.3)$ & \\
\hline$\square>12$ month & $14(70.0)$ & $4(100.0)$ & $18(75.0)$ & \\
\hline$\square \quad$ Never & $2(10.0)$ & $0(0.0)$ & $3(12.5)$ & \\
\hline Total & $\begin{array}{l}20(100.0) \\
32\end{array}$ & $4(100.0)$ & $24(100.0)$ & \\
\hline
\end{tabular}




\begin{tabular}{|c|c|c|c|c|}
\hline \multicolumn{5}{|l|}{$\begin{array}{l}\text { 7. Last time new stock was } \\
\text { introduced }\end{array}$} \\
\hline$\square \quad 1-6$ months & $3(15.0)$ & $1(25.0)$ & $4(16.7)$ & \\
\hline$\square \quad 7-12$ months & $5(25.0)$ & $1(25.0)$ & $6(25.0)$ & 0.706 \\
\hline$\square>12$ months & $7(35.0)$ & $2(50.0)$ & $9(37.5)$ & \\
\hline$\square \quad$ Never & $5(25.0)$ & $0(0.0)$ & $5(20.8)$ & \\
\hline Total & $20(100.0)$ & $4(100.0)$ & $24(100.0)$ & \\
\hline \multicolumn{5}{|l|}{$\begin{array}{l}\text { 8. Handling of new stock before } \\
\text { adding to the herd }\end{array}$} \\
\hline$\square 2$ weeks of quarantine & $1(5.0)$ & $0(0.0)$ & $1(4.2)$ & \\
\hline$\square 2$ weeks of quarantine and deworming & $0(0.0)$ & $2(50.0)$ & $2(8.3)$ & 0.000 \\
\hline $\begin{array}{l}\square 2 \text { weeks of quarantine, deworming and } \\
\text { oxytetracycline TLA inj. }\end{array}$ & $0(0.0)$ & $2(50.0)$ & $2(8.3)$ & \\
\hline$\square$ Nothing & $19(95.0)$ & $4(95.0)$ & $19(79.2)$ & \\
\hline $0(\mathbf{1 0 0 . 0})$ & $4(100.0)$ & & $24(100.0)$ & \\
\hline
\end{tabular}

\section{Discussion}

The information obtained from the 24 herdsmen revealed that herd management practices posed some risks of acquiring haemoparasitic infections in both pastoralist and sedentary herds in the study area. For instance, ticks and biting flies were reported by the herdsmen to be responsible for the transmission of haemoparasites in both herds in Soba LGA of Kaduna State. This may be attributed to the favourable weather in the northern guinea savannah which supported their breeding and distribution as reported by Okorafor and Nzeako (2014).

Most of the herdsmen controlled vectors by hand picking of ticks on cattle and repelling of biting flies through smoking especially in the pastoralist herds while other herdsmen practiced hand picking only or dipping and or use of pour-on application. This hand picking of ticks by the herdsmen tends to create a favourable entry points for opportunistic bacteria such as Dermatophilus congolense which causes dermatophilosis in cattle. Another problem of hand picking of ticks is that a herdsman may not notice all ticks or by the time they are noticed, the ticks might have already transmitted the parasites to the host cattle. Most of the herdsmen controlled these vectors anytime they appeared in the herds especially in the pastoralist herds while some herdsmen controlled theirs in wet season only by dipping and or use of pouron especially in sedentary herds. This type of herd management practice should be done strategically to disrupt the life cycles of the vectors due to their global distribution as reported by Okorafor and Nzeako, (2014). Majority of the herdsmen had grazed their cattle within some known tsetse flies infested areas in the last 1-2 years especially those practicing pastoralist herd management system. Other herdsmen had never visited tsetse flies infested areas especially those of the sedentary herds. This practice of seasonal grazing in Glossina infested areas should be discouraged because when the herds migrate back to their bases, the sedentary herds may acquire the infection through other biting flies predominant in the study area as were reported by the herdsmen during the interview.

Lack of screening and strategic treatment of herds against haemoparasites were not common among herdsmen due to the subclinical nature of the haemoparasitic diseases (Luckins, 1992). The herdsmen in this study only did so when the haemoparasites disease began to affect 


\section{Danbirni, Daudu, Saidu and Tekdek}

production. This finding agreed with the report of Luckins, (1992). The similarity in the risk of acquiring haemoparasites in both pastoralist and sedentary herds was when new stock was added to the existing herds within 1-12 months or more, than those that never added. This may indicate similar precautions accorded to new arrivals. Majority of the herdsmen did not do anything before adding a new stock, while others practiced a 2-week of quarantine period only or with deworming and administration of oxytetracycline long acting injection. This may be due to the fact that majority of the herdsmen preferred to purchase the apparently healthy replacement stock with good body condition scores before adding them to their herds. A few of them had bought their new stock during periods of nutritional stress due to feed scarcity. This kind of stress might have lowered the immune system of the cattle and might eventually render them susceptible to any disease most especially those with subclinical infections at the point of purchase.

\section{Conclusions}

Ticks and biting flies (100.0\%) as reported by both pastoralist and sedentary herdsmen were the only arthropod vectors that may be involved in the transmission of haemoparasites to cattle in Soba LGA of Kaduna State. Some farm management practices such as non-screening of herds for haemoparasites $(75.0 \%)$, their treatments once in more than 12 months $(75.0 \%)$ and lack of quarantining of new stock before adding to the herds (79.2\%) constituted risk to having haemoparasitism in the study area. Communal dipping and application of pour-on, especially on weekly basis for vector control in the herds should be encouraged. Herds and new stock should be screened and treated for haemoparasites as the case may be, especially at the beginning of the dry season when herds are on a nutritional stress due to feed scarcity. It is envisaged that this survey will stimulate more studies to determine the prevalence of haemoparasites in cattle in Soba LGA of Kaduna State.

\section{Acknowledgement}

We acknowledged the support and cooperations of herdsmen that participated in this study. The technical contributions of Professors A. K. B. Sackey, P. A. Abdu and Dr. Faruk Umar are well appreciated.

\section{References}

Akande, F. A., Takeet, M. I. and Maka n j u, O. A. 2010 . Haemoparasites of cattle in Abeokuta, South-West Nigeria. Science World Journal, 5(4): 1921.

Biu, A. A. and Kabono, A. 2005. Prevalence of bovine haemoparasites in Maiduguri, Nigeria. Journal of Experimental and Applied Biology, (6): 27-31.

Ellis, J. T., Morrison, D. A. and Reichel, M. P. 2003. Genomics and its impact on parasitology and the potential for development of new parasite control methods. DNA and Cell Biology, 32: 395-403.

Dold, A. P. and Cocks, M. L. 2001. Traditional Veterinary Medicine in the Alice District of the Eastern Cape Province, South Africa. South African Journal of Science, 97(910): 375379.

Dreyer, K. Fourie, L. J. and Kok, D. J. 1998. Tick diversity, abundance and seasonal dynamics in a resource poor urban environment in the Free State Province. Ondersteport Journal of Veterinary Research, 65:305-316.

Ellis, J. T., Morrison, D. A. and Reichel, 
M. P. 2003. Genomics and its impact on parasitology and the potential for development of new parasite control methods. DNA and Cell Biology, 32: 395-403.

Ikhatua, U. J. and Asaka, M. E. 2000. Effects of feeding grass forage supplement with rice bran-based concentrate diets on the performance and blood characteristic of West African Dwarf Goats. Unpublished data. Cited with permission as quoted by Paul et al.,(2016).

International Livestock Research Institute (ILIR). 1997. Livestock, people and the Environment. ILIR, Nairobi, Kenya.

Jongejan, F. and Uilenberg, G. 2004. The global importance of ticks. Parasitology, (129): S3S14.

Kamani, J., Sannusi, A., Egwu, O. K., Dogo, G. I., Tanko, T. J., Kemza, S., Tafarki, A. E.

and Gbise, D. S. 2010. Prevalence and significance of haemoparasitic infections of cattle in NorthCentral Nigeria. Veterinary World Journal, 3(10): 445-448.

Lamorde, A. G. 1998. Scenario building for the Nigerian livestock industry in the $21^{\text {st }}$ century. A paper presented at the Silver Anniversary Conference of the Nigerian Society for Animal Production at Gateway Hotel, Abeokuta, Nigeria. March 21-26, 1998.

Lorusso, V., Picozzi, K., de Bronsvoort, B. M., Majekodunmi, A., Dongkum, C., Balak, G., Igweh, A. and Welburn, S. C. 2013. Ixodid ticks of traditionally managed Cattle in Central Nigeria: where Rhipicephalus (Boophilus) microplus does not dare (yet $\square$ ) Parasites Vectors, 6: 171.
Luckins, A. G. 1992. Trypanosomosis in small ruminants- a major constraint to livestock production. British Veterinary Journal, 148: 471-472.

Musa, H. I., Jajere, S. M., Adamu, N. B., Atsanda, N. N., Lawal, J. R., Adamu, S. G. and Lawal, E. K. 2014. Prevalence of tick infestation in different breeds of cattle in Maiduguri, north - eastern Nigeria. Bangladesh Journal of Veterinary Medicine, 12(2): 161-166.

Obadiah, H. I. and Shekaro, A. 2012. Survey of Tick Infestation in Cattle in Zaria Abattoir, Nigeria. Journal of Veterinary Advances, 2(2): 8187.

Okorafor, U. P. and Nzeako, S. O. 2014. Prevalence of haemoparasites of cattle from three abattoirs in Ibadan metropolis, Oyo State, Nigeria. International Journal of Scientific Research and Environmental Science, 2(7): 244-249.

Salih, D. A., Hussein, A. M. and Singla, L. D. 2015. Diagostic approaches for tick-borne haemoparasitic diseases in livestock. Journal of Veterinary Medicine and Animal Health, 7(2): 45-56.

Samdi, S. M., Abenga, J. N., Attahir, A., Haruna, M. K., Wayo, B. M., Fajinmi, A. O., Sumayin, H. M., Usman, A. O., Hussaina, J. Z., Muhammad, H., Yamap, J. E., Ovbagbedia, R. P. and Abdullahi, R. A. 2010 . I mpart of trypanosomosis on food security in Nigeria: A review: International Journal Animal and Veterinary Advances, 2(2): 47-50.

Singla, L. D., Aulakh, G. S. and Juyal, P. D. 2007. Haemato-biochemical and Clinicpathological observations on haemoprotists in cattle and buffaloes. Proceedings of National 
Seminar on recent diagnostic trends and control strategies for haemoprotozoan infections in livestock held on February 09-11, 2007 at Sardarkrushinagar, Gujarat, pp. 107-110.

Received: $10^{\text {th }}$ September, 2018 Accepted: $21^{\text {st }}$ December, 2018 